\title{
Kultura nordycka i gotyk jako miejsca wspólne w wirtualnej rzeczywistości. Reprezentacja historycznych stylów na wybranych przykładach komputerowych gier fantasy
}

Nordic culture and the gothic as commonplaces in virtual reality. Representation of historical style in selected examples of fantasy computer games

\section{Michał Szymański}

Uniwersytet im. Adama Mickiewicza w Poznaniu markchagall90@wp.pl | ORCID: 0000-0002-4550-7679

\begin{abstract}
The purpose of the article is to consider the relationship between computer games and cultural heritage, which is a testimony to specific historical epochs. Inspiration of the old architecture, sculpture and painting, in the form of quotes or allusions, occurs in many games, which allows us to talk about a separate phenomenon that requires research. A look at the games from the perspective of an art historian allows us to see many new aspects of creating virtual worlds by game developers. Examples include fantasy games that broadly refer to cultural heritage. The text discusses examples of several productions that reproduce the art of a specific period, focusing on the repertoire of selected themes. The analyses are preceded by a presentation of the state of research regarding the issue of interpretation of history in computer games. The criticism of historical simplification in games by one of the researchers is the basis for further reflection on the positive aspects of interpreting the past in fantasy games.
\end{abstract}

Keywords: computer games, historical hertitage, Gothic style, Nordic art 



\section{Wstęp. 0 budowaniu miejsc wspólnych w grach komputerowych}

Niniejszy artykuł ma na celu podjęcie refleksji na temat wykorzystywania motywów historycznoartystycznych w grach komputerowych. Na potrzeby tekstu zostało wybranych kilka gier cyfrowych, które powstały w ostatnich latach. Biorąc pod uwagę zaobserwowane w nich inspiracje stylistyczne, omawiane produkcje przyporządkować można do dwóch nurtów: sztuki nordyckiej i gotyku. Liczne nawiązania do szeroko rozumianego dziedzictwa historycznego skłaniają do zastosowania pojęcia miejsc wspólnych (Bogdanowska, 2008, s. 23; Curtius, 1997, s. 5), które twórcy w tym wypadku budują za pomocą projektów lokacji składających się na świat gry. Elementy znane $\mathrm{z}$ innych mediów w znacznym stopniu konstruują strukturę rzeczywistości danej gry, stanowiąc nieodłączną część rozgrywki. Współtworzą warstwę wizualną gier, a implementacja tych elementów wiąże się także z propagowaniem dziedzictwa historycznego. Jak można przypuszczać, ta ostatnia praktyka przeważnie nie jest głównym celem twórców, którzy przede wszystkim mają zaoferować graczowi jak najbardziej atrakcyjny produkt finalny. Na ten efekt składa się wciągająca swoimi rozwiązaniami rozgrywka i ciekawy projekt wizualny świata. Przy tym coraz częściej widać, że inspiracje dawną spuścizną kulturową stanowią istotny element kształtujący wizualną sferę w wielu współczesnych grach.

Pełna, satysfakcjonująca interpretacja fikcyjnego świata² danej gry wymaga odpowiednich kompetencji kulturowych. Można tu zadać pod-

${ }^{1}$ Odnoszę się tutaj do gotyku w jego najbardziej klasycznej formie, znanej szczególnie z kamiennych katedr francuskich powstających w okresie dojrzałego i późnego okresu rozwoju tego stylu, między XIII a XV wiekiem.

${ }^{2}$ Pojęcie tego używam za Kendallem Waltonem i Marie-Laure Ryan, według których „fikcyjne światy” są kreowane w różnych mediach, zarówno literackich, jak i wizualnych. Niezależnymi od medium wspólnymi aspektami tych światów są charakterystyczne miejsca, postacie i wydarzenia, które je tworzą (Walton, 1990, s. 63, 210; Ryan, 2014, s. 1). Wskazane zjawisko zostało również zaimplementowane na gruncie gier cyfrowych, które oferują graczowi interaktywne przemierzanie rozbudowanych światów, a stopień ich rozległości warunkuje rozgrywkę, którą można podzielić na otwartą i linerarną (zob. Friedman, 1995, s. 133; Tavinor, 2007, s. 68). Podanych kryteriów nie spełniają pewne rodzaje gier, w tym abstrakcyjne gry logiczne. Szczególnie uwarunkowane do kreowania fikcyjnych swiatow są gry przygodowe lub z gatunku RPG, których twórcy mniej lub bardziej świadomie nawiązują do rozwiązań stylistycznych znanych z historii sztuki, odnosząc się do określonych wzorców. 
stawowe pytanie: czy istotnie gracze mają szansę choćby ogólnie uchwycić kontekst kulturowy, w jakim sytuuje się dana produkcja? Tym bardziej problematyczne może wydawać się rozpoznanie określonej stylistyki czy aluzji do danego dzieła. Na analogie między elementami świata obecnymi w grach a innymi tworami kultury wizualnej można jednak spojrzeć z szerszej perspektywy, odnosząc się do problematyki rozpowszechniania i utrwalania „wizualnych stereotypów”. Zwykle w odbiorze społecznym słowo „stereotyp” ma wydźwięk pejoratywny i jest rozumiane jako zbiór negatywnych cech, trwale przypisanych danej grupie lub pojęciu - np. kategorii stylu (Schweinitz, 2011, s. 12). Jednak sam twórca tego terminu, Walter Lippman, ujął stereotypy jako rodzaj „obrazów w umyśle", które służą do tworzenia mniej lub bardziej spójnego wyobrażenia o świecie, bazującego na ogólnych kategoriach. Funkcją stereotypu jest upraszczanie bardziej złożonych idei i utrzymywanie stabilnego systemu myślenia o rzeczywistości (Lippmann, 1997, s. 53-55). Takie kategoryzacje nieraz kształtowane są pod wpływem antypatii, ale na podstawowym poziomie pozwalają na uczenie się i poznawanie świata bez konieczności ciągłego powtarzania tych samych procesów (Jonáš, 2013, s. 297-299).

W tym świetle stereotypy nie są tylko zbiorem powierzchownych sądów o rzeczywistości, ale również próbą syntetycznego ujęcia danego zjawiska, aby łatwiej było je zrozumieć i w ten sposób uporządkować wiedzę na określony temat. Za próbę taką można też uznać wyobrażenia wizualne (obrazy, wyglądy - np. lokacji w grach), które powstały według kanonu ukształtowanego w danej kulturze. Pewne dzieła z uwagi na wyróżniającą się formę wizualną szczególnie utrwalają się w zbiorowej pamięci i w późniejszych interpretacjach uchodzą za reprezentacje postaw czy światopoglądów charakterystycznych dla określonej epoki. Rozwiązania formalne łączące grupę dzieł stanowią podstawę do określenia i zdefiniowania odrębnego stylu. Na przykład, jak wskazuje Jörg Schwenitz, skonwencjonalizowany język kinematografii składa się na rodzaj stereotypu. Tworzą go elementy w rodzaju konstrukcji postaci czy technik filmowych, takich jak sposób komponowania kadrów oraz różne rodzaje montażu. Upowszechnienie niektórych z tych rozwiązań w wielu filmach tworzy z czasem schemat, który kształtuje masową wyobraźnię (Schweinitz, 2011, s.3). Natomiast na gruncie historii sztuki Arnold Hauser pisze o „stereotypowym stylu”, na który składają się ustalone 
formuły wizualne. Sposób rozmieszczenia postaci na obrazie, ich gesty czy symboliczne przedstawienie przedmiotów badacz uważa za rodzaj kulturowego kodu zaakceptowanego przez artystów i odbiorców, który tworzy język sztuki (Harris, 2003, s. 4).

Ernst Gombrich określa ten zbiór powtarzalnych rozwiązań wizualnych mianem „konwencji przedstawieniowych”. Jego zdaniem stanowią one punkt odniesienia dla artystów, dostosowujących je do swojej wizji ${ }^{3}$. Rozpoznanie owych konwencji w zakresie filmu, malarstwa i innych dziedzin kultury wizualnej nie stanowi wyłącznie domeny badaczy. Współczesny odbiorca dzięki internetowi ma stosunkowo łatwy dostęp do najróżniejszych, poddanych cyfryzacji tworów kultury i poświęconych im opracowań. Wyposażony w takie narzędzia i przy odrobinie wysiłku poznawczego każdy ma możliwość zapoznania się z szerokim repertuarem konwencji wykorzystywanych $\mathrm{w}$ dziełach $\mathrm{z}$ różnych mediów. Inną kwestią jest ich dokładne nazwanie czy klasyfikacja, ale brak specjalistycznych kompetencji nie stanowi przeszkody dla podstawowego, ogólnego rozpoznania danego motywu. Te powtarzalne w kulturze wizualnej motywy tworzą wskazane wcześniej miejsca wspólne, którymi mogą być zarówno konwencje stylistyczne, jak i konkretne obiekty o ikonicznym statusie ${ }^{4}$.

\section{Recepcja dziedzictwa historycznego w grach komputerowych. Ogólny zarys problemu}

Dynamiczny rozwój grafiki komputerowej w ostatnich latach zaczął sprzyjać promowaniu kulturowego dziedzictwa historycznego. Genezę tego zjawiska można zaobserwować w przypadku gier tworzonych już trzy dekady wcześniej. Wówczas, pomimo stosunkowo mało rozwiniętych

\footnotetext{
${ }^{3}$ Autor prezentuje przykład przedstawień rzymskiego Zamku św. Anioła w niemieckiej sztuce. Na tej podstawie rozwija swoją tezę dotyczącą tego, jak rzeczywisty wygląd obiektu i stereotyp wchodzą w symbiozę, kształtując dane przedstawienie zgodnie z „idealnym” wyobrażeniem (Gombrich, 1981, s. 61-68).

${ }^{4}$ Funkcjonowanie w zbiorowej pamięci obrazów miejsc, w których pamiętający mogli nie być, trafnie ujmuje także koncepcja „miejsc wyobrażonych” zaproponowana przez Hansa Beltinga. Wyjaśniając ją, badacz powołuje się na przykład wierszy chińskich poetów. Ich opisy pejzaży na tyle utrwaliły się w lokalnej kulturze, że czytelnicy rozpoznawali dane miejsce, choć mogli go nigdy nie widzieć (Belting, 2009, s. 1055).
} 
możliwości silników graficznych, niektóre produkcje podejmowały tematy związane $\mathrm{z}$ historią sztuki, a wiele $\mathrm{z}$ nich $\mathrm{w}$ ograniczonym stopniu wykazywało także potencjał edukacyjny. Opisując to zainteresowanie, w pierwszej kolejności można wskazać na inspiracje antykiem w kulturze popularnej, obecne w wielu współczesnych mediach. Wykorzystywane wcześniej szeroko w filmach, komiksach czy animacjach dla dzieci, rozpowszechniły się również wśród gier cyfrowych.

Wczesnym przykładem owej recepcji jest gra przygodowa ${ }^{5}$ Perseus and Andromeda z 1983 r. (Chmielewska, 2016, s. 179), w której historia była opisywana w formie narracji tekstowej, a mechanika rozgrywki opierała się wyłącznie na wpisywaniu prostych komend. Narracja w grze została zilustrowana niezwykle uproszczonymi w formie, statycznymi grafikami opartymi na konturach, nie zawsze wypełnionymi kolorem ${ }^{6}$. Jakość prezentowanych w grze grafik współcześnie można byłoby porównać do rezultatu stosowania narzędzia systemowego Paint. Z czasem temat mitologii i kultury greckiej został przetransponowany do produkcji o bardziej rozbudowanym interfejsie graficznym i bardziej złożonej mechanice rozgrywki. W tym względzie szczególnie należy wyróżnić gry strategiczne, a wśród reprezentantów gatunku podejmujących recepcję kultury antycznej można wymienić m.in. Zeus: Master of Olympus z 2000 r. oraz Age

${ }^{5}$ Określa się tym mianem typ gier popularnych w latach siedemdziesiątych i osiemdziesiątych opartych na wpisywaniu bądź wyborze komend tekstowych odnoszących się do akcji wykonywanych przez gracza. Istotą rozgrywki było rozwiązywanie zagadek i dokonywanie wyborów wobec nakreślonych krótkim opisem sytuacji (Schell, 2008: 143-144). Czasem określało się te produkcje zamiennie jako przygodowe gry tekstowe (text adventure game), a za ich pierwszy znany przykład uznawany jest tytuł Collossals Cave Adventure z $1975 \mathrm{r}$. Liczba możliwych komend posuwających rozgrywkę dalej była w istocie często ograniczona do prostych poleceń jak „podnieś” lub „popatrz”. Z czasem, wraz z ewolucją możliwości sprzętowych, omawiane produkcje ewoluowały w gry przygodowe określane jako „point and click” (Rollings, Adams, 2003: 443-445). Te pozwalały graczowi za pomocą kursora wchodzić w interakcje z elementami dwuwymiarowego, w niektórych częściach animowanego tła poprzez znalezienie i zastosowanie w odpowiednim miejscu przedmiotu, aby odblokować przejście do następnego etapu rozgrywki. Niektórzy badacze jako pierwsze gry przygodowe traktowali MUD (Multi-User Dungeons) o interfejsie tekstowym, łączącym graczy przez internet (Aeserth, 1997, s. 4). Z uwagi na mnogość definicji i dynamiczny rozwój gatunków łączących wiele mechanik termin ten obecnie ma jeszcze szersze zastosowanie, obejmuje różne typy gier.

${ }^{6}$ Zagadnienie to zostało szerzej opracowane w zbiorowej publikacji: Antiquity in Popular Literature and Culture (Dominas, Wesołowska, Trocha, 2016). 
of Mythology z 2002 r. Potencjał oferowany przez mitologiczne historie spowodował również, że motywy wywodzone z mitów greckich zaimplementowano w grach osadzonych w pełnym środowisku trójwymiarowym, czego interesującym przykładem jest gra z gatunku action RPG - Rise of the Argonauts z 2008 r., w której gracz prowadzi w walce tytułowych Argonautów Jazona.

Wśród produkcji zawierających odwołania do kultury antycznej wyróżnia się nowsza produkcja o tytule Apotheon z 2015 r., która reprezentuje nurt gier niezależnych (independent games). Na szczególną uwagę zasługuje warstwa wizualna ze względu na stylizację grafiki w konwencji czarnofigurowego malarstwa greckiego. Apotheon czerpie inspiracje z tego stylu w rozbudowanej grze platformowej, wzbogaconej przez system walki oparty na stosowaniu historycznej broni (Szymański, 2017). Oprócz gier łączących wątki mitologiczne $\mathrm{z}$ odniesieniami kulturowymi osobną grupę stanowią produkcje związane $\mathrm{z}$ wydarzeniami historycznymi. Za początek kształtowania się tego nurtu należy uznać serię gier Civilization, której pierwsza część pojawiła się w 1991 r. Celem graczy w tej serii jest rozwój wybranej cywilizacji poprzez wybór technicznych, naukowych i militarnych odkryć. W równym stopniu co ekspansja terytorialna istotny jest rozwój kulturowy i ekonomiczny miast wybranej frakcji (Anderson, McLoughin, Liarokapis, 2010, s. 54). Twórcy oferują graczowi uniwersalną drogę rozwoju dla wszystkich nacji, niezależnie od ich położenia geograficznego i kultury. Zadaniem produkcji jest przedstawienie wybranych zjawisk historycznych - najważniejszych zdaniem autorów gry.

Obecnie twórcy w większym zakresie korzystają z wiedzy ekspertów, obrazując podejmowane zagadnienie bardziej szczegółowo i przy wykorzystaniu bardziej zaawansowanej technologii cyfrowej (Walker, 2003, s. 178-179). O jakościowym postępie w sposobie prezentacji kontekstu historycznego w grach świadczy cykl Total War, np. Rome Total War, Mediewal Total War czy Shogun Total War. Serię cechuje duży nacisk na realistyczne ukazanie bitew, w tym wyglądu jednostek danej frakcji oraz stosowanych przez nie taktyk wojskowych (Anderson, McLoughin, Liarokapis, 2010, s. 60).

W wyniku dążenia deweloperów do tworzenia symulacji historii wyodrębnił się nurt cyfrowych gier o charakterze historycznym, które można zakwalifikować do szerokiej grupy interaktywnych zabaw edukacyjnych 
zwanych serious games ${ }^{7}$. Nacisk na interesującą rozgrywkę jest w nich mniejszy niż w komercyjnych grach wideo. Tutaj mieszczą się realistyczne, interaktywne wizualizacje tworzone w środowisku 3D, których celem jest przekazywanie wiedzy w interesujący sposób. Dobrym przykładem jest projekt Roma Nova, w którym gracz przemierza starożytny Rzym około roku 320 n.e. (Anderson, McLoughin, Liarokapis, 2010, s. 2-3).

Wskazane powyżej projekty są znacznie mniej popularne od komercyjnych realizacji ostatniej dekady, których światy są co prawda usytuowane w historycznym kontekście, ale przeplatają go z fantastycznymi motywami i dowolnie przekształcają. Ważnym przykładem jest seria Assassin's Creed, której pierwsza część została wydana w 2007 r., a ostatnia, o podtytule Valhalla, w 2020 r. Każda część przenosi gracza w inną epokę, oferując rozgrywkę wpisaną w odpowiednie wydarzenia historyczne. Kolejno to III krucjata, renesansowe Włochy za czasów wielkich wpływów Medyceuszy, Ameryka Północna w okresie walk o niepodległość Stanów Zjednoczonych, Wyspy Karaibskie w XVIII w., Paryż podczas rewolucji francuskiej, XIX-wieczny Londyn czy starożytny Egipt i Grecja. Natomiast najnowsza część rozgrywa się na ziemiach Anglosasów w IX w. podczas inwazji wikingów. Charakterystycznym aspektem wszystkich części cyklu stała się próba oddania specyfiki architektury słynnych miast w danej epoce.

\section{Mity historyczne a kulturowe wyobrażenie wikinga}

Wskazane powyżej przykłady świadczą o tym, że dziedzictwo historyczne jest licznie reprezentowane w grach komputerowych, choć należałoby się zastanowić nad rezultatem owej recepcji. Istotnym punktem odniesienia w tej refleksji będzie artykuł Michała Sołtysiaka, który stwierdza, że sposób przedstawiania dziedzictwa historycznego w grach często pozostaje $\mathrm{w}$ napięciu z ustaleniami historycznymi. Autor wpisuje zdiagnozowane zjawisko w szerszy proces związany z powielaniem mitów kulturowych

\footnotetext{
${ }^{7} \mathrm{~W}$ poświęconej zagadnieniu serious games książce Clark Abt włącza w ten obszar różne formy zabaw, które podporządkowane były celom edukacyjnym. Zaobserwował przykłady takich lekcji z uczniami szkół średnich i studentami już w latach sześćdziesiątych (Abt, 1987, S. 11, 25, 40).
} 
i stereotypizacją wiedzy historycznej (Sołtysiak, 2015, s. 193-194). Przykładem utrwalania tego rodzaju obrazów przeszłości jest według autora wizerunek wikingów, prezentowanych jako prymitywni wojownicy z rogami na hełmach. Relacje dotyczące brutalnej ekspansji przysłoniły znaczenie ich działalności kolonialnej i wkładu w rozwój kultury podbitych terytoriów.

Michał Sołtysiak uważa, że w tym zakresie gry sięgają do wyobrażeń wywodzonych z kultury wizualnej XIX w., co zaobserwowali wcześniej inni badacze (Frank, 2000; O’Donoghue, 2007, s. 120-125). Szczególną uwagę poświęca charakterystycznym hełmom z rogami, które utrwaliły się w popkulturowym wizerunku tych wojowników, pomimo że jedynymi ich świadectwami były znaleziska $\mathrm{z}$ epoki żelaza, poprzedzające kulturę określaną ogólnie jako wikingowie. Przykładów gier powielających ten kulturowy stereotyp dostarcza seria Civilization, w której wódz wikingów i niektóre jednostki noszą rzeczony hełm z rogami. Niemniej zdaniem badacza bardziej kontrowersyjnym przykładem jest analogiczny wizerunek wojownika na okładce Medieval Total War: Viking Invasion. To przykład znaczący, ponieważ produkcja należy do serii gier strategicznych cechujących się rzetelnością w oddawaniu realiów historycznych. Zarazem żadna z jednostek podczas rozgrywki nie nosi tego rodzaju ozdoby hełmów. Badacz ocenia, że zastosowane uproszczenia stanowią jedynie sposób na promocję gier, ponieważ wpisują się w wyobrażenia potencjalnego odbiorcy na temat danej cywilizacji (Sołtysiak, 2015, s. 197-203).

Przytoczone przez autora gry bezzasadnie dystansują się od materiału źródłowego i jedynym wyjaśnieniem wprowadzanych rozwiązań są aspekty marketingowe. Jednocześnie wiele produkcji unika tak podstawowych błędów historycznych. W tym względzie wskazać można m.in grę Twierdza (Stronghold), serie RTS Age of Empires i Anno czy cykle reprezentujące gatunek FPS takie jak Medal of Honor i Battlefield. Z pewnością można w nich dostrzec wiele uproszczeń w sposobie prezentacji historii, ale wynikają one głównie z przystosowania wymienionych produkcji względem mechaniki rozgrywki. Nie zaburzają natomiast spójności w odbiorze fikcyjnych światów osadzonych w realiach historycznych. 


\section{Między mitem kulturowym a recepcją historii}

Sołtysiak porusza również temat gier fantasy, które jego zdaniem zastępują historyczne przesłanki o danej kulturze jej mitycznym wyobrażeniem. Rozważanym w artykule przykładem jest The Elder Scrolls V: Skyrim, który jak słusznie zauważa autor, pomimo fikcyjnej natury przedstawionego świata ewidentnie bazuje na kulturze nordyckiej. Sołtysiak przywołuje temat fakultetu prowadzonego na Rice University, „Scandinavian Fantasy Worlds: Old Norse Sagas and Skyrim", dotyczącego nawiązań do sag ludów północy zawartych w grze. Uznaje, że badanie recepcji tekstów w oderwaniu od oryginalnego kontekstu jest częścią szerszego zjawiska zwanego neomediewalizmem. Zawierający się $\mathrm{w}$ tym pojęciu proces transpozycji średniowiecznej kultury przez mity kulturowe bezpośrednio dotyczyć ma również przytoczonej przez autora gry, zwłaszcza że była ona promowana wizerunkiem wojownika w hełmie okularowym $\mathrm{z}$ rogami (Sołtysiak, 2015, s. 202-204).

Nie odejmując słuszności przywołanemu stanowisku, wskazane zjawisko można potraktować również w kategoriach mitologizacji kultury. W tym kontekście relacja między elementami mitycznymi i „realnymi” jest bardziej złożona i opiera się na wymienności i nieustannym przenikaniu. Nadawanie wydarzeniom historycznym cech mitu lub uwierzytelnianie legendarnych opowieści odwołaniami do historii jest z kolei nieodłącznie związane z każdą kulturą od czasów najdawniejszych do współczesnych (Czeremski, 2015, s. 21-23). Przykładem niech będzie bitwa przy moście mulwijskim, z którą związana jest opowieść o śnie Konstantyna I poprzedzającym starcie. Cesarz ujrzał ponoć na niebie znak krzyża i pod wpływem tej wizji miał kazać umieścić symbol na tarczach żołnierzy walczących w zwycięskiej dla niego bitwie (Rodriguez, 2011, 10-14). Innym, ogólniejszym przykładem jest obecność mitycznych stworzeń, jak gryf i smok, na herbach wielu szlacheckich rodów, a nawet w godłach państwowych. W tym względzie łączenie wątków historycznych i ponadnaturalnych stanowi element kultury, którego odzwierciedleniem są dzieła tworzone w różnych mediach, w tym gry komputerowe. Część badaczy gier podkreśla, że wielu twórców świadomie zestawia światy fantastyczne ze stylistyką inspirowaną historycznymi rozwiązaniami i kompiluje te wątki w nowy twór (Bissel, 2010, s. 57; Fordham, 2012, s. 52). 
W tym miejscu należy podkreślić, że niezależnie od intencji twórców współczesnych tekstów epickich recypujących przeszłość nie powinno się ich traktować w kategoriach dokumentów historycznych. Mogą wyłącznie implementować różne aspekty przeszłości z mniejszą lub większą dokładnością. Twórcy gier fantasy wydają się w pełni świadomi tego procesu i zazwyczaj twórczo wykorzystują ową synergię.

Zasadne zdaje się tu przytoczenie pojęcia historyzmu. Tradycyjnie definiuje się je jako próbę uhistorycznienia refleksji na temat danej kultury i jej wartości, które są czasowe i tym samym ukonstytuowane w historii (Beiser, 2011, s. 2; Troeltsch, 2006, s.178). Włączenie opisanego myślenia w XIX-wieczną praktykę akademicką uczyniło z historyków badaczy, którzy na nowo odkrywają badane źródła, a nie je biernie rekonstruują (Meinecke, 2003, s. 15). Zdefiniowany w ten sposób historyzm zawiera aspekt kreatywnego myślenia o przeszłości, choć należy podkreślić, że wcześniej historyzm - postrzegany w kategoriach nurtu artystycznego posługującego się wypracowanymi uprzednio stylami - był postrzegany pejoratywnie. W ocenie wybitnych historyków sztuki XX w. architektura historyzmu była schematycznym kopiowaniem wzorców wynikającym z niemożności wypracowania własnego stylu (Pevesner, 1973, s. 20). Ponadto uznawano ją za symptom choroby trawiącej wówczas europejską kulturę, która "potrafi jedynie imitować, a nie tworzyć” (Sedlmayr, 2007, s.102-105). We współczesnych popularnych opracowaniach historyzm opisuje się na równi z eklektyzmem i uznaje oba nurty za wtórne i kompilatorskie (Górzyński, 2013, s.4-5). Niemniej odbiór historyzującej sztuki przez znawców jest obecnie daleki od wcześniejszej oceny (zob. Bałus, 2011). Odniesienie do danego stylu historycznego jest wszak syntezą przeszłości i tego, co aktualne, prowadzącą często ku nowemu rezultatowi poznawczemu.

Akcentując znaczenia, jakie niesie synergia spotkania tego, co przeszłe, z teraźniejszym, warto przywołać perspektywę intertekstualną, rozumianą tutaj jako metoda pozwalającą badać związki między dziełami różnych mediów i epok (Czekalski, 2006, s.9). Relacje te są niejednokrotnie złożone i wychodzą poza podstawowe kategorie wpływu czy bezpośredniej, niepodważalnej zależności od danego twórcy lub dzieła (Hemeren, 2018, s.322-323). Wykazanie zależności między wybranymi dziełami kultury wymaga określenia łączących je cech. Przeprowadzenie takiego porównania ma potencjał do poszerzenia wniosków względem 
przeprowadzonej wcześniej interpretacji, opartej na analizie struktury samego dzieła (tamże, s. 207-208).

Podchodząc podobnie do światów kreowanych w grach komputerowych, warto zwrócić uwagę na potencjalne źródło ich inspiracji. Pewne elementy tych światów są inspirowane motywami wywodzącymi się z wcześniejszych kultur, co wpływa w dużej mierze na prezentowaną wizję artystyczną. Prowadzi to do kreowania nowej, twórczej przestrzeni, która istnieje w odniesieniu do dzieła powstałego w innym czasie, ale jego znajomość nie jest warunkiem koniecznym do oddziaływania na odbiorcę. Jednakże ustalenie zaistnienia wskazanej relacji niewątpliwie wzbogaca i pogłębia rozumienie danego zjawiska w kulturze wizualnej.

\section{Nordycka kultura w grach fantasy}

W tym świetle należałoby pozytywnie spojrzeć na rolę, jaką odgrywają produkcje fantasy w rodzaju wzmiankowanego The Elder Scrolls V: Skyrim. Poza powieleniem wskazanego już mitu kulturowego gra na wielu innych poziomach także czerpie $\mathrm{z}$ dziedzictwa wikingów. Eksplorowane przez gracza miasta, m.in. Biała Grań, Gwiazda Zaranna i Smocza Przystań, zarówno pod względem układu, jak i wyglądu niektórych budowli mają pewne cechy dużych wikińskich grodów. W najwyższym punkcie wzmiankowanych lokacji znajduje się dom jarla, w którym rezyduje wódz danej społeczności. Domostwo wyróżnia się pośród innych obszerną, długą izbą z dużym, kamiennym paleniskiem w centrum (Teva, 2013, s. 50-53). Układ miast w grze nie tylko odpowiada ogólnym ustaleniom archeologicznym na temat siedlisk wikingów, ale jest funkcjonalny z perspektywy rozgrywki i pozwala graczowi stosunkowo łatwo zorientować się w położeniu najważniejszych punktów. Poszczególne drewniane domostwa są łatwo rozpoznawalne i dekorowane motywem plecionki ${ }^{8}$. „Scenografię" większych miast dopełniają także łodzie zacumowane w przystani, które swoim wyglądem i wielkością przypominają te używane przez wikingów

\footnotetext{
${ }^{8}$ Motyw plecionki w ornamentyce stanowią horyzontalne pasy złożone z połączenia wzorów roślinnych i figuralnych w formie przeplatanych ze sobą figur zwierząt i fantastycznych stworzeń. Występujące na chatach układy plecionki zwieńczone głowami zwierząt przypominają styl mammen, który występował między 1000 a 1075 r. (Mazza, 2015, s. 5-8).
} 
w ich dalekich, morskich wyprawach' ${ }^{9}$ W grze zaimplementowano również wątki mitologiczne, w podziemnych kryptach umieszczając draugów, nieumarłych wojowników ${ }^{10}$, którzy stają się przeciwnikami gracza.

Innymi wrogimi, bardziej istotnymi dla fabuły postaciami są smoki pojawiające się w nordyckich opowieściach, takie jak Fafnir (Lindow, 2010, s. 110). Starcia ze smokami stanowią standardowy element wielu gier fantasy RPG, ale w tym przypadku został on uzasadniony na gruncie podań kultury nordyckiej. Synteza sfery fantasy i kultury wikingów w rozgrywce widoczna jest również w magii używanej przez naszą postać, a właściwie sposobu jej prezentacji. Na pewnym etapie rozwoju fabuły gracz rozwija tzw. drogę głosu i w tym celu poszukuje „słów mocy” wyrytych na ścianach podziemnych świątyń. Ich forma przypomina wczesny alfabet runiczny, co otwiera nowe konteksty. Runy miały głównie cel komunikacyjny, ale z czasem zaczęto im przypisywać magiczne, sprawcze właściwości. Umieszczenie odpowiednich znaków na danym przedmiocie miało mu nadać szczególne cechy ${ }^{11}$. Nawiązaniem do nordyckiej kultury są także trzy identycznie obrobione skały z wygrawerowanymi na ich powierzchni wizerunkami, które gracz napotyka na wzgórzu w początkowym etapie gry. Po podejściu do każdego z monolitów na ekranie ukazuje się napis określający nazwę przedmiotu: „kamień maga”, „kamień wojownika” i „kamień złodzieja”. Tak została zaimplementowana mechanika wyboru klasy postaci, co w innych grach RPG ma miejsce przed rozpoczęciem rozgrywki, w trybie kreatora postaci. Sam kształt megalitów też jest istotny, ponieważ nasuwa jednoznaczne skojarzenie z kamieniami

${ }^{9}$ Typów tych łodzi było kilka, a w grze występują przynajmniej dwa rodzaje, które z uwagi na cechy formalne zdają się nawiązywać do konstrukcji nazywanych drakkar, snejkk i karvi (Shaw, 2016, s. 13-17).

10 Byli to ożywieni zmarli, pochodzący pierwotnie z wierzeń islandzkich, którzy powstali ze śmierci z powodu złych uczynków za życia lub dręczeni niedokończonymi sprawami. Draugrowie po odrodzeniu zazwyczaj trzymali się niedaleko miejsc pochówku, by pilnować rzeczy, z którymi ich pochowano (Jakobsson, 2011, s. 186)

${ }^{11} \mathrm{Na}$ magiczne znaczenie wskazuje mit o Odynie, który po dziewięciu dniach wiszenia na drzewie świata Yggdrasil uzyskał za to poświęcenie znajomość run. Umiejętność pisania w alfabecie runicznym składającym się z 24 liter, funkcjonującym w tej formie od II wieku n.e. do ok. XIII, nie była powszechna. W związku z tym zaczęto je traktować nie tylko jako podstawę języka pisanego, ale też źródło magicznej siły sprawczej. Wierzono na przykład, że pobarwienie danych run nada im szczególną moc, która będzie chronić daną osobę lub przyniesie jej szczęście w określonej dziedzinie życia (Roberston, 1976, s. 318-319). 
runicznymi, których nadal wiele można napotkać w różnych krajach Skandynawii (MacLeod, Mess, 2008, s. 211).

Kolejną produkcją, która w warstwie fabularnej odwołuje się do mitów nordyckich, a wizualnie czerpie z materialnej kultury wikingów, jest God of War z 2018 r. Poprzednie trzy części tej samej serii również powstały na mitologicznej kanwie, ale w świecie starożytnej Grecji. Historia bohatera opartego na micie heraklejskim ${ }^{12}$ pokazuje jego drogę do zemsty nad bogami. Najnowsza część cyklu oferuje graczowi świat znany ze skandynawskich mitów oraz zupełnie nowy typ rozgrywki i jakość graficzną. Wyobrażenie świata dawnych Skandynawów tworzą tutaj zarówno zimowe pejzaże, jak i obiekty architektoniczne oraz mniejsze przedmioty rzemiosła artystycznego. Skrzynie, dzięki którym postać uzyskuje dostęp do skarbów oraz surowców, zostały wyróżnione motywem plecionki, ornamentem stemplowym oraz dekoracją roślinno-figuralną, typowymi dla sztuki nordyckiej ${ }^{13}$. Analogicznymi wzorami pokryte są przedmioty należące do głównego bohatera: topór oraz napierśnik. Ich dekoracje są ryte na żelaznym ostrzu lub występują w formie aplikowanych, złoconych okuć, co również jest charakterystyczne dla sztuki nordyckich kultur o wysoko rozwiniętym rzemiośle artystycznym ${ }^{14}$. Wynika $\mathrm{z}$ tego, że przedmioty istotne z perspektywy rozgrywki zostały wyróżnione pod względem wizualnym.

Przejścia do istotniejszych pomieszczeń zaakcentowano natomiast płycinami, w których ukazane płaszczyznowo figury wojowników zostają zestawione $\mathrm{z}$ formami abstrakcyjnymi ${ }^{15}$. Motywem wizualnym ściślej wpisanym

${ }^{12}$ Główny protagonista serii Kratos reprezentuje typ antybohatera, pragnącego zemsty na bogach. W brutalny sposób zabija swoich przeciwników. Jednocześnie pewne elementy fabuły łączą jego historię z Heraklesem, jak na przykład zamordowanie własnej rodziny i towarzyszące temu piętno. Postać Kratosa stała się przedmiotem kilku osobnych artykułów (Futflänger, 2012; Chmielewska, 2016).

${ }^{13} \mathrm{~W}$ grze widoczna jest inspiracja kilkoma formami ornamentalnymi znanymi z nordyckiej sztuki ery wikingów. Dekoracje na wybranych skrzyniach przypominają styl borre, stosowany między 850 a 950 r. n.e., a na innych - styl oseberg, znany pomiędzy 800 a $875 \mathrm{r}$. (Graham-Campbell, 2013, s. 26, 80).

${ }^{14} \mathrm{~W}$ tym przypadku zdobienia przypominają raczej styl zwany urnes, występujący w XI i XII w., charakteryzujący się stosowaniem prostych ornamentalnych wici (Mazza, 2015, s. 4-11).

${ }^{15}$ Przenikanie się motywów figuralnych i ornamentalnych jest powszechne w tej sztuce. Tkanina z Overhogdal dobitnie pokazuje charakterystyczne cechy wynikające z tego połączenia (Graham-Campbell, 2013, s. 158). 
w narrację gry są drewniane tablice $\mathrm{z}$ dwoma skrzydłami, które pokryte zostały przedstawieniami ilustrującymi epizody znane z mitologii nordyckiej. Syn Kratosa objaśnia mu ich znaczenie, co określa dystans obu postaci wobec niektórych wydarzeń mitologicznego świata. Tym sposobem pozycjonują się jako zewnętrzni, obiektywni obserwatorzy, funkcjonujący poza ramami mitycznej opowieści, pomimo że z perspektywy gracza sami są jej bohaterami. Podkreślającym to zabiegiem formalnym jest kontrast między ukazanymi profilowo wizerunkami w pozbawionych głębi perspektywicznej scenach a fotorealistyczną grafiką reszty przedstawionego świata, która ma charakter niemal filmowy. Specyfikę ukazanej przestrzeni podkreśla również pismo runiczne pokrywające ściany wielu eksplorowanych kamiennych ruin, powierzchnie drzwi oraz mniejsze przedmioty. Ponadto runy pojawiają się wraz z komunikatem o rozpoczętej lub zakończonej misji, zatem są używane w komunikacji systemu z graczem.

Wielokrotnie syn bohatera musi odczytywać treść runicznych inskrypcji w celu rozwiązania danej zagadki środowiskowej ${ }^{16}$ i poprowadzenia postaci do dalszego etapu historii. Znaki runiczne są także powiązane z mechaniką ulepszania ekwipunku poprzez opatrzone nimi drobne kamienie, nadające wybranym przedmiotom nowe właściwości. Nawiązuje to do przekonania o rzekomej mocy pewnych obiektów pokrytych runami, które według wierzeń pełniły rolę amuletów ${ }^{17}$. Proces ulepszania przedmiotów również został włączony w mitologiczne nawiązania poprzez wprowadzenie postaci dwóch kowali: Sindriego i Brokki, należących do rasy karłów (Lindow, 2010, s.99-100), którzy pomagają naszemu protagoniście. Inną mityczną postacią włączoną w warstwę

16 Wśród graczy określa się tym terminem rodzaj wyzwania oparty na interakcji z różnymi elementami otoczenia. Rozwiązanie zagadki jest konieczne, aby posunąć rozgrywkę na dalszy etap. W omawianej grze często napotykamy liczne zamknięte bramy. Ich otwarcie wymaga uruchomienia pewnych mechanizmów w określonej sekwencji lub wyboru właściwych obiektów. O tym, jaki zakres działań powinien w tym celu podjąć Kratos, informuje go jego syn, który odczytuje i objaśnia mu znaczenie run dotyczących danej zagadki.

${ }^{17}$ Niekiedy na wyrost przypisywano wikingom wiarę w magiczne właściwości większości kamieni i przedmiotów opatrzonych runami. Wynikało to często z nieznajomości pisma runicznego przez przybyszy z zewnątrz, zwłaszcza w początkowej fazie chrystianizacji, oraz ze staroskandynawskich, mitycznych opowieści, w których tajemne właściwości run były często podkreślane. Niektórym nadawano znaczenie ochronne, a jeśli miały charakter wotywny, dedykowany danemu bóstwu, wiązało się to również z jego protekcją (Macleod, Mees, 2008, s. 71, 120, 158). 
fabularną jest Freja, która zgodnie z jej opisem w podaniach posługuje się w grze magią. Pojawia się też stanowiący własność bogini magiczny dzik, z którym również związane są nordyckie legendy. Inną istotną dla fabuły postacią jest bóg Baldur, który okazuje się głównym antagonistą Kratosa, a mit o nim (Lindow, 2010, 124-128) zostaje zaadaptowany na potrzeby historii wykreowanej w grze.

Bardzo interesująca jest kreacja przemierzanych mitycznych regionów, takich jak Nilfheim i Jotunheim, których estetyka odpowiada opisom znanym z nordyckich sag (Lindow, 2010, s. 206, 234, 240). Wyobraźnia twórców uzupełnia pobieżne i ogólne przekazy na temat tych krain w źródłach pisanych poprzez wypełnienie lokacji charakterystyczną architekturą. Z jednej strony nawiązuje ona do tradycji rzemiosła artystycznego wikingów, a z drugiej cechujący ją monumentalizm podkreśla boski charakter przemierzanych krain. Efekt uzyskano między innymi za pomocą rozmieszczenia ogromnych posągów Thora i figur normańskich wojowników flankujących mosty i przejścia w danej lokacji. Szczególny monumentalizm cechuje lokację o nazwie Świątynia Tyra, z uwagi na ogromny most i plac zdobione ornamentami w formie złotych okręgów wypełnionych różnorodnymi wzorami. Warto zaznaczyć także obecność dużych złocistych pater ustawionych na cokołach oraz wielkich, pełnowymiarowych głów smoków, stylizowanych zgodnie ze wzorami znanymi z kultury wikingów ${ }^{18}$.

Nieco odmienne cechy wizualne ma zamieszkana przez rasę elfów kraina Alfheim. W tym przypadku wyróżniającym aspektem stylistycznym jest filigranowość konstrukcji, opartych na długich łukach ostrych oraz smukłości elementów dążących ku górze. Prostota form architektonicznych jest spójna $\mathrm{z}$ ich elegancką dekoracją, a wymienione cechy pozwalają na porównanie do architektury gotyckiej. Ponadto wyrazistym elementem omawianych konstrukcji jest światło, które po aktywowaniu odpowiednich kryształów tworzy mosty łączące się z platformami wykonanymi z tradycyjnych materiałów. Rola światła wpisuje się zarówno w koncepcję średniowiecznej architektury, jak i Tolkienowski opis krainy zamieszkiwanej przez elfy (Tolkien, 2001, s.463-465). Poza tym przedstawiona charakterystyka jest zgodna $\mathrm{z}$ ogólnym wyobrażeniem

18 Takimi elementami cechuje się styl helling, stosowany pomiędzy 900 a $975 \mathrm{r}$. (Mazza, 2015, s. 7-8). 
o architekturze tej rasy wynikającym z Władcy Pierścieni. Ekranizacja książek pisarza także podkreśla lekkość, liczne łuki i wizualne otwarcie budowli elfów, co można zaobserwować również w omawianym God of War. Nie bez znaczenia pozostaje to, że w kreacji świata Władcy Pierścieni pisarz inspirował się sagami nordyckimi.

Reasumując, choć architektura w grze jest fantastyczną kreacją, to bardzo silnie widoczne są w niej inspiracje, które pozwalają na wgląd w sztukę kultur nordyckich. Wykazane nawiązania odgrywają istotną rolę w kreacji przedstawionego świata i są włączone w jej warstwę narracyjną oraz niektóre elementy mechaniki rozgrywki. Inspiracja elementami kultury materialnej wikingów oraz jej późniejszą recepcją posłużyła twórcom do zbudowania spójnego stylistycznie świata, który opierając się o określone wzorce, ma jednak indywidualny charakter.

Poprzednie przykłady dotyczyły gier wykorzystujących tropy mityczne i motywy wizualne z klasycznego fantasy, w które zostały włączone zapożyczenia historycznoartystyczne. Warto na koniec zestawić z nimi wizję kultury nordyckiej z najnowszej odsłony Assassin's Creed o podtytule Valhalla. Podobnie jak we wcześniejszych częściach cyklu, świat przedstawiony ma charakter synkretyczny ${ }^{19}$, ale dominuje tendencja do sytuowania rozgrywki w określonych realiach historycznych. Twórcy osadzają akcję w IX w., czyniąc protagonistą gry wojownika z Norwegii, który wraz z grupą towarzyszy udaje się na podbój ziem anglosaskich. Eksplorując królestwa średniowiecznej Angliii ${ }^{20}$, przemierzamy duże miasta, takie jak Lincoln, Jorvik (obecnie York) czy Lunden (znany potem pod nazwą Londynu). Ich zbudowane z kamienia mury, mosty, kościoły i inne elementy architektoniczne można porównać z dzisiejszymi obiektami, częściowo zachowanymi lub zrekonstruowanymi.

Specyfikę regionu oddają rozmieszczone gdzieniegdzie, kojarzone jako miejsca kultu święte kręgi w gajach, menhiry i miejsce, którego wygląd stanowi jawne odniesienie do Stonehenge. Oprócz tego uwzględniono

19 Łączy kontekst historyczny z pewnymi elementami mitologicznymi, a nawet wprowadza do tego wątki fantasy i science fiction obecne od drugiej odsłony serii.

${ }^{20}$ Wówczas Anglia podzielona była między cztery regiony rządzone przez niezależnych władców, nazywane: Wessex, Essex, Northumbia i Kent. Były one stopniowo kształtowane na zrębach dawnej prowincji rzymskiej Britannii po ostatecznym odejściu z wyspy ok. 410 r. n.e. legionów chylącego się do upadku imperium (Nelson, 1997, s. 30-31). 
relikty hegemonii imperium rzymskiego na tych terenach w postaci fragmentów murów, antycznych rzeźb czy ruin świątyń ${ }^{21}$.

Natomiast lokacje w Norwegii, ściślej odnoszące się do kultury nordyckiej, obejmują początkowy etap gry, stwarzając wrażenie przemierzania tych rejonów geograficznych już w zakresie krajobrazu. Lokalna architektura tego okresu prezentowana jest poprzez liczne, otoczone palisadą grody z drewnianymi domami i posągami, które wpisują się w ogólne wyobrażenie o kulturze wikingów - podobnie jak przycumowane $\mathrm{w}$ wielu miejscach łodzie różnego typu, oddane przy tym dość szczegółowo, z uwzględnieniem różnic w ich wyglądzie. Ponadto wiele z nich może zostać użytych przez postać gracza jako środek transportu istotny w rozgrywce, nie są więc jedynie elementem uzupełniającym historyczną scenografię miast.

W kontekście specyfiki nordyckiej architektury w grze szczególnie należałoby wyróżnić monumentalny obiekt o nazwie „horholl” w miejscowości Stavanger. Jego funkcja nie jest sprecyzowana, ale eksploracja oświetlonych świecami wnętrz z drewnianymi posągami wojowników sugeruje miejsce kultu bogów nordyckich. Jednakże charakterystyczna forma budowli wskazuje na inspiracje kościołami typu słupowego, które powstawały w Norwegii między X a XII w., stanowiąc świadectwo połączenia kultury rodzimej z rosnącymi wpływami chrześcijańskimi (Kuren, 2007, s. 64-67). Świadczy o tym złożona $\mathrm{z}$ wielu segmentów, stopniowo spiętrzona ku górze bryła $\mathrm{z}$ dachami dominującymi w oglądzie całości, odpowiednio zestawione deski tworzące podstawową strukturę budowli czy wieńczące krańce dachów detale architektoniczne w formie stylizowanych smoków. Najbardziej temu opisowi odpowiada świątynia w Borgund, a także w Bergen ${ }^{22}$.

W Assassin's Creed Valhalla relacja z prezentowanym kontekstem historycznym jest wyraźnie zaznaczona na gruncie fabuły, nazw i wrażenia

\footnotetext{
${ }^{21}$ Inną kwestią pozostaje zakres występowania tych pozostałości antycznej kultury, które w grze napotkać można stosunkowo często, i to niekiedy w dość dobrze zachowanym stanie. Jeśli uwzględnimy upływ pięciu wieków od zakończenia panowania imperium rzymskiego na tych terenach, a zwłaszcza budowanie na jego zrębach własnej kultury materialnej przez lokalne plemiona, mało prawdopodobne wydaje się tak rozległe zachowanie tego dziedzictwa.

22 Powstanie obu obiektów datuje się na połowę XII w. (Kurek, 2017, s. 67), a więc znacznie późniejszy okres niż czas fabularny gry. Niemniej świątynie w tym typie powstawały już od X w. w Norwegii, a wspomniane budowle, w dużej części zrekonstruowane, zachowały się do dziś i mogły być wzorcem dla projektantów lokacji.
} 
realizmu w oddaniu detali obiektów, co wzmaga poczucie autentyzmu przemierzanych lokacji. Jednocześnie gra obejmuje wyselekcjonowany wycinek obszaru obu krajów ${ }^{23}$, niektóre elementy są wyolbrzymione lub uproszczone z powodu niemożności weryfikacji stanu faktycznego pewnych obiektów z przeszłości. Zarazem Valhalla stanowi wyjątek wśród gier z widocznymi ambicjami osadzenia rozgrywki w historycznej rzeczywistości. Wynika to z przynależności do serii, której twórcy za cel stawiają sobie możliwie wierne odtworzenie tła historycznoartystycznego danej epoki i aby to zrealizować, lata temu wypracowali wciąż udoskonalany system mechanik i związanych z nim rozwiązań wizualnych.

Przykładem tego ostatniego może być wpływ sposobu ukształtowania fasad budynków i układu miejskiej przestrzeni na interakcje postaci gracza z otoczeniem. Rodzaj i liczba elementów architektonicznych artykułujących zarówno główne fasady, jak i wszystkie ściany budowli pozwalają postaci wspiąć się na zwieńczenie każdej z nich. Ponadto odpowiednie odległości między budynkami umożliwiają swobodne przeskakiwanie na kolejne obiekty, ułatwiając przemieszczanie. Dzięki tym rozwiązaniom prowadzona przez gracza postać może szybko przedostać się w określony punkt miasta, unikając przechodzenia ulicą, lub uciec przed konfrontacją ze strażnikami.

\section{Gotyk i neogotyk jako wzorce wizualne w grach studia FromSoftware}

Przykładami świadczącymi o kluczowym znaczeniu inspiracji konkretnym stylem artystycznym w kreacji fantastycznego świata są najnowsze gry studia FromSoftware, takie jak trylogia Dark Souls. Wszystkie produkcje tej serii cechuje niezwykłe bogactwo wizualnych odniesień, najsilniej skupionych wokół średniowiecznej i nowożytnej architektury europejskiej. Japońskie studio FromSofware buduje złożone, przesycone symboliką światy, które całościowo są fikcyjne, ale można z nich wyodrębnić style zakorzenione w kulturze epok historycznych. Przedmiotem poniższego krótkiego studium będzie kilka wybranych lokacji z trzeciej odsłony

${ }^{23}$ W Norwegii to jedynie region o nazwie Rygjafylke, obecne określany mianem Rogaland. 
trylogii. Zawierają one różnorodne odniesienia do wielu miejsc i stylów, ale wprawny obserwator dostrzeże dominację danego nurtu. Zacznijmy od Carthuskich Katakumb, złożonych z zespołu jaskiń, które mogą kojarzyć się z pogańskimi miejscami kultu ukazywanymi często w filmach przygodowych. W jednej z sal najsilniejszą dominantę stanowią potężne filary ustawione w czterech szeregach, a stylistyka dolnej, najbardziej masywnej części nasuwa skojarzenia ze świątyniami subkontynentu indyjskiego, szczególnie Halą Kolumn w świątyni Jain na terenie Rankapur. Wskazane zestawienie wzmacnia poczucie przebywania w miejscu mistycznym, a jasny układ pomieszczenia pozwala klarownie rozeznać się w potencjalnym kierunku ruchu.

$\mathrm{Na}$ rozwinięcie wątku symbolicznego naprowadza znajdujący się w centrum sali stół z kielichem o czarze zrobionej z czaszki. Miejsce usytuowania obiektu oraz charakterystyczny wygląd kielicha skłaniają gracza do podejścia i wówczas dochodzi do starcia z przeciwnikiem: Wielkim Władcą Wolnirem, olbrzymim szkieletem, który stopniowo wyłania się z ciemności. Wizualny projekt tej postaci pozwala na porównanie z wyglądem kielicha. Na tej podstawie należy wysnuć wniosek o powiązaniu tego miejsca $\mathrm{z}$ motywem śmierci i religijnego rytuału. $\mathrm{Z}$ kolei zestawienie stołu i kielicha z określeniem „katakumby” ukierunkowuje skojarzenia w stronę chrześcijaństwa. Obecność wspomnianych kolumn komplikuje tę interpretację, choć wspólny pozostaje motyw śmierci i odrodzenia, obecny w wielu religiach. Najsilniej kontrastuje z tym otoczeniem rozbudowany portal prowadzący do kolejnego pomieszczenia. Jego cechy świadczą o inspiracji stylem barokowym, a nietypowy wygląd należy wyjaśnić intencją wyróżnienia przejścia za pomocą bardziej wyrafinowanej formy. Nadal jednak mamy do czynienia z symboliką sakralną, ponieważ portale takie najczęściej prowadziły do wnętrz kościołów. W kolejnym, prostym w formie jaskiniowym pomieszczeniu również pojawia się portal, którego stylistyka jeszcze silniej kontrastuje z resztą wnętrza. Przy tym jego obecność jest uzasadniona charakterem wizualnym kolejnej lokacji o zbliżonych cechach. Gotycka forma portalu sygnalizuje graczowi panoramiczny widok na analogiczną stylowo lokację o nazwie Ithryll w Mroźnej Dolinie.

Utrzymanie tego miejsca w chłodnej ciemnoniebieskiej tonacji odróżnia je od ciemnych katakumb oświetlonych ciepłym światłem świec i nakreśla odmienny charakter obu przestrzeni. Pośród widocznej ze wzniesienia 
bryły miasta wyróżnia się jedna, najwyższa budowla, której fasada ma cechy francuskiej katedry gotyckiej. Zostaje ona dodatkowo zaakcentowana poprzez aurę jasnoróżowego światła przypominającego łunę. W ten sposób wizualnie zaakcentowano cel, do którego powinien zmierzać gracz. Styl lokacji kreuje również charakterystyczny długi most z tralkami, a szczególnie poprzedzająca go brama. Jej konstrukcja i zdobnictwo, z ostrołukowym przejściem przypominającym portal oraz flankującymi je wieżami, też przypominają katedrę gotycką. W tym miejscu pojawia się przeciwnik o wyglądzie czworonożnego monstrum, który znacznie przewyższa siłą naszego bohatera. Otwarty most, sygnalizujący początkowo bezpieczną drogę, wiąże się z poczuciem zagrożenia. Pomocne okazują się konstrukcja i długość gotyckiego mostu, umożliwiające szybki bieg przed siebie w stronę zamkniętego placu. Otaczający go pierścień budowli oraz obiekty w oddali tworzą kompleks o stylowo spójnym charakterze, a architektoniczno-rzeźbiarska forma w centrum placu umieszczona jest blisko ogniska, które pełni rolę punktu zapisu postępów w rozgrywce.

Rozciągające się powyżej schody ponownie budzą poczucie zagrożenia związane z przeciwnikami, których wygląd odpowiada stylowi dominującemu w tej lokacji. W ten sposób układ lokacji i sposób jej wizualnego opracowania wpisują się w elementy mechaniki rozgrywki, wpływając na całościowy odbiór. Okute w lekką zbroję szkielety noszą na głowie wysokie, złote korony ze zwiewnym woalem. Powoli poruszający się przeciwnicy przypominają zjawy, które ze względu na otoczenie można skojarzyć z upiorami opisywanymi w powieściach gotyckich ${ }^{24}$. Opisując otoczenie, należałoby podkreślić znaczenie rzeźb, które flankują główną drogę prowadzącą do wysokiej bramy, powtórnie przypominającej portal kościoła. Ustawione na cokołach postacie są odziane w obszerne szaty, a ich poza pozwala na porównanie z modlącymi się pątnikami, wzmacniając sakralne konotacje lokacji. Średniowieczną scenografię uzupełniają figury rycerzy ustawione bezpośrednio na dziedzińcu za bramą, które trzymają dłonie na rękojeściach mieczy wbitych w posadzkę. Natomiast

${ }^{24}$ Nazwa gatunku literackiego, a z czasem konwencji filmowej, które określiły pewien repertuar motywów i rozwiązań, jakie przetrwały do dnia dzisiejszego. Istotne było otoczenie, w jakim rozgrywała się historia, i kreowana za jego pomocą atmosfera. Średniowieczne ruiny, opuszczone domy i stare miasta to typowa scenografia gotyckiego horroru (Balk, 2011, s. 4-5). 
powyżej umieszczone są figury ukazujące dwóch mężczyzn z nakryciem głowy w formie infuły i w szatach przypominających ornat. Na sakralną symbolikę wskazują też trzymane przez nich przedmioty. Postać z lewej dzierży bowiem kostur o wyglądzie stylizowanym na pastorał, a w dłoniach drugiej figury umieszczony został kielich. Opisane postacie rycerzy i biskupów można zaliczyć do dwóch typów postaw, vita activa i vita contemplativa, a te - potraktować jako metakomentarz do charakteru całej rozgrywki. W realiach Dark Souls III gracz postawiony zostaje w sytuacjach umieszczających go pomiędzy stanem kontemplowania wizualnego piękna danej lokacji a koniecznością agresywnej walki przeciwko umieszczonym w niej istotom.

Misterna aranżacja przestrzeni ma przy tym wyłącznie charakter symboliczny, ponieważ zamknięty plac nie prowadzi do pożądanego fabularnie celu. Górująca nad placem katedra okazuje się niedostępna $\mathrm{z}$ tego punktu ${ }^{25}$. Analiza jej fasady z dużą dekoracyjną rozetą i trójkątnym tympanonem nasuwać może skojarzenie z południową fasadą transeptu (nawy poprzecznej) katedry Notre-Dame w Paryżu. Nadaje to miejscu szczególne znaczenie, które znajdzie swój wyraz w końcowym etapie tego poziomu. O roli budowania aluzji do sfery chrześcijańskiego sacrum w tej lokacji świadczy także niewielkie ciemne wnętrze innej budowli, do którego wchodzi gracz po odnalezieniu właściwej drogi. Układ i opracowanie elementów upodabniają wnętrze do kościoła w typie świątyni halowej. Wskazane skojarzenie wzbogaca wyodrębniony obszar pomieszczenia oddzielony łukiem, który wraz z prostym kamiennym stołem upodabnia tę część do prezbiterium. Układ przestrzeni zyskuje znaczenie dzięki obecności ogniska na skrzyżowaniu naw, które - jak wcześniej wskazano - służy do zapamiętania stanu gry. Tutaj postać odradza się w przypadku śmierci i jest to ostatni bezpieczny obszar w lokacji, stanowiący rodzaj azylu wobec zagrożeń czekających postać gracza w dalszym etapie. Zaciszne wnętrze małego kościoła kontrastuje z monumentalną przestrzenią wzmiankowanej wcześniej katedry, w której gracz musi się zmierzyć z końcowym przeciwnikiem (tzw. bossem).

\footnotetext{
${ }^{25}$ Dotarcie w to miejsce nie wiąże się także z zyskaniem dodatkowego przedmiotu lub z zadaniami pobocznymi, których fabuła gry jest pozbawiona Stosowanie takich rozwiązań może mieć na celu kreowanie poczucia przemierzania otwartego świata i zagubienia w nim, pomimo że w praktyce struktura rozgrywki jest linearna.
} 
Pierwszy człon nazwy określającej tego przeciwnika („Pontyfik Sulyvahn") wywodzi się od terminu pontifex, na początku oznaczającego najwyższego kapłana w starożytnym Rzymie, a od V w. będącego tytułem papieskim (Cameron, 2016, s. 139). Mijane wcześniej upiory noszą miano „rycerzy pontyfika”, co nadaje im status jego strażników i wpływa na percepcję eksplorowanego wcześniej miasta. Dystynkcję przeciwnika podkreślają obszerne szaty przypominające ornat, srebrna maska i złota, otwarta korona oraz układ i wystrój miejsca walki. Przestronne wnętrze nawy głównej przeciętej nawą poprzeczną (transeptem) to oczywiście plan krzyża łacińskiego, a układ ten zarówno pełni tu rolę symboliczną, jak i wpisuje się w mechanikę rozgrywki ${ }^{26}$. Umieszczone w nawie drewniane ławy są naturalną barierą osłaniającą przed ciosami bosa, ale mogą zostać przez niego łatwo zniszczone. Wówczas należy przenieść walkę w kierunku ramion transeptu, które z jednej strony umożliwiają łatwiejsze ukrycie, a z drugiej strony narażają na zablokowanie pod wpływem napierających ciosów Pontyfika Sulyvahna. Opuszczenie wnętrza przed pokonaniem przeciwnika uniemożliwia pojawiająca się po wejściu do katedry nieprzekraczalna mgła spowijająca otwory wejściowe z obu stron. Gdy gracz odniesie zwycięstwo, mgła rozprasza się i odsłania przejście do następnego etapu rozgrywki (w prezbiterium katedry pojawia się wówczas kolejne ognisko). Projekt opisanych lokacji opiera się więc na konsekwentnym dialogu ze stylem gotyckim, co ma zasadniczy wpływ na odbiór estetyczny i sposób rozgrywki.

Ostatnim przykładem będzie gra Bloodborne z $2015 \mathrm{r}$. autorstwa tego samego studia. Ze względu na silne podobieństwa z poprzednimi produkcjami FromSoftware klasyfikowana jest do podgatunku nazywanego soulslike. W rozgrywce istotnie występują podstawowe zbieżności w poziomie trudności gry i typie wyzwań, sposobie zapamiętywania bieżących

26 Zwykle budowle gotyckie miały trójnawowy korpus główny. Wskazany układ przestrzenny budowli w grze stanowi wobec tego uproszczenie, które wpływa na możliwości ruchu postaci gracza w starciu z bossem. Zastosowanie trójnawowego planu korpusu głównego zmieniłoby charakter walki, postać gracza miałaby bowiem możliwość chwilowego osłonięcia się przed atakami, chowając się w nawach bocznych. Przestrzeń została więc odpowiednio dostosowana do założeń rozgrywki w tej lokacji. Niemniej obecność dużych nisz zamkniętych arkadą w bocznych ścianach nawy głównej można interpretować jako nawiązanie do powszechnego w gotyku założenia przestrzennego, świadczące o świadomości twórców w tym zakresie. 
postępów i zdobywania doświadczenia przez postać gracza. Wspólny jest również ogólny język wizualny, który syntetycznie można scharakteryzować jako mroczny horror gotycki. Tutaj jednakże zostaje to zrealizowane jeszcze bardziej spójnie poprzez konsekwentne utrzymanie tej konwencji w warstwie wizualnej od pierwszej do ostatniej lokacji - i to w każdym najmniejszym detalu.

Gracz prowadzi postać tropiciela potworów mającego w ciągu jednej nocy wyeliminować zagrożenie z miasta Yrhnam. Z krótkiego, dość enigmatycznego $\mathrm{w}$ przekazie przerywnika filmowego otwierającego historię oraz nielicznych dialogów dowiadujemy się o istnieniu instytucji „Kościoła uzdrowienia”, w imię którego zostaliśmy wybrani do zwalczenia skutków zarazy zamieniającej ludzi w bestie. W zarysowanej w ten sposób narracji kluczowy aspekt stanowi sceneria, sytuująca rozgrywkę na tle XIX-wiecznego, neogotyckiego miasta, które tworzy ramy dla mrocznej, przepełnionej symboliką opowieści. Obraz ponurego miasta tworzą strzeliste kamienne budowle z licznymi ostrołukami, umieszczone w niszach rzeźby, liczne schody, mosty oraz nagrobki i metalowe trumny. Specyficzne doświadczenie eksploracji tak wykreowanego miasta wzmacnia aura nocy i okrywająca niektóre miejsca mgła. Ciemne ulice rozświetlają wyłącznie pochodnie i niewielkie, bardzo niskie latarnie, współtworząc atmosferę niepokoju i tajemniczości. W tym otoczeniu gracz konfrontuje się z mieszczanami spaczonymi nieokreśloną chorobą o znamionach klątwy, wilkołakami i innymi człekokształtnymi potworami, które stanowią oryginalną transpozycję monstrów wywodzących się z XIX-wiecznych powieści grozy.

Projekt miasta Yhrnam ukazuje konsekwencję twórców w wykorzystaniu stylu neogotyckiego. Oprócz uogólnionych, swobodnie wykorzystywanych formuł tej architektury gracz natrafia niekiedy na aluzje do wyglądu konkretnych budowli. Długi kamienny most przemierzany w pierwszym etapie rozgrywki pozwala na porównanie z mostem Karola w Pradze. Świadectwem inspiracji jest nie tylko wielkość mostu, ale także rzeźby rozmieszczone po jego obu stronach. Ich stosunkowo regularne rozlokowanie na wysokich cokołach w skrajnych partiach mostu wykazuje pewne podobieństwa względem ustawienia figur na praskim zabytku. Różnice objawiają się w braku symetrii rozmieszczenia rzeźb oraz szczegółach budowy niskiego muru obwodzącego most, który w Bloodborne zostaje 
urozmaicony tralkami. Istotniejszym przetworzeniem w stosunku do założenia praskiego zabytku jest jednak ulokowanie mostu w obrębie ulic, a nie rozpięcie go nad rzeką. Ponadto twórcy zrezygnowali z charakterystycznego rozwiązania w postaci wieży bramnej. Tworzy to ciąg komunikacyjny umożliwiający przedostanie się na i pod przęsło mostu poprzez różne skróty. Sam most natomiast pozbawiony zostaje standardowej funkcji ${ }^{27}$ na rzecz roli areny starcia z pierwszym bossem, Bestią Kleryka. Długie i szerokie przęsło pozwala uniknąć ataków wysokiego przeciwnika o dużym zasięgu ramion, a zarazem przemieszczać się do punktu który umożliwia uderzenie i wycofanie się bez ryzyka zablokowania lub wypadnięcia poza obręb mostu.

Innym interesującym przykładem odwołania do znanego obiektu jest przysadzista wieża z tarczą zegarową podobna do Big Bena, części kompleksu parlamentu londyńskiego. W grze szczyt wieży został wykorzystany jako punkt obronny dla jednego z łowców, który ostrzeliwuje naszą postać za pomocą broni maszynowej. Jej budowa nawiązuje do kartaczownicy Gatlinga ${ }^{28}$ stosowanej podczas ostatniej fazy wojny secesyjnej. Podobnie jak w powyższym przykładzie wieża wpisuje się $\mathrm{w}$ proponowaną $\mathrm{w}$ grze stylistykę, tym razem jako budowla wyraziście neogotycka. Jednakże również w tym przypadku estetyka obiektu została dostosowana do potrzeb rozgrywki: wieża nie ma hełmu, co zaburza jej proporcje, pozwala jednak dostrzec $\mathrm{z}$ daleka wrogo nastawionego łowcę i odpowiednio zareagować.

Wartym uwagi nawiązaniem do historyzującej stylistyki jest też opracowanie wizualne całej lokacji o nazwie „Sen Tropiciela”, do której gracz przenosi się za pomocą małych latarni rozmieszczonych w poszczególnych punktach miasta. Lokacja nabiera znaczenia z perspektywy fabuły oraz mechaniki rozgrywki. Stąd gracz przenosi się pomiędzy odkrytymi wcześniej miejscami, tutaj rozwija statystyki swojej postaci oraz ma

${ }^{27} \mathrm{Na}$ most prowadzą osobne schody boczne, a przejścia z obu końców są zamknięte, a więc pod względem funkcjonalności w układzie miasta jego obecność nie byłaby uzasadniona.

${ }^{28}$ Broń maszynowa zaprojektowana przez Richarda Gatlinga i użyta po raz pierwszy w 1860 roku. Była to ruchoma broń wielolufowa, wystrzeliwująca pociski przy użyciu dźwigni bądź korby. Poprzedzała wynalezienie karabinu automatycznego (Keller, 2008, s. 60-65). 
możliwość zaopatrzenia się w przedmioty potrzebne podczas eksploracji niebezpiecznego miasta. Na stosunkowo niewielkim terenie rozmieszczone są płyty grobowe, które służą do przenoszenia się między wspomnianymi latarniami. Wyobrażenie cmentarza dopełniają niewielkie białe postaci o wyglądzie wzorowanym na duszkach kodoma, znanych $\mathrm{z}$ folkloru japońskiego ${ }^{29}$.

Na niewielkim wzniesieniu powyżej znajduje się „Domek Gotycki”, do którego prowadzi główna, wybrukowana głazami droga. Jego wyłożone drewnem wnętrze jest stylizowane analogicznie do dekoracji zewnętrznej i w tym miejscu bohater ma sposobność do ulepszenia swojej broni białej oraz palnej, co sugerują zawieszone na ścianie narzędzia. Wewnątrz rezyduje starzec na wózku - Gherman, Pierwszy Łowca - który nadzoruje działania i stanowi ważną postać w fabule Bloodborne. Atmosferę tajemniczości i grozy wzmacnia również ogromny księżyc ponad domem, zawsze widniejący na niebie w tym samym miejscu. Sceneria ulega metamorfozie w finalnym etapie gry, podczas którego księżyc nabiera krwistoczerwonej barwy, a zamknięta dotychczas żelazna brama prowadzi teraz do nowego obszaru cmentarnego ogrodu. Teren pokrywają połacie białych kwiatów i w wielu punktach rozmieszczone sąliczne nagrobki oraz krzyże tau, których ramiona pokryte są roślinnością sugerującą obecność rozpostartych na nich postaci.

Oniryczną atmosferę, zgodną z nazwą tego miejsca, dookreśla gęsta biała mgła otaczająca ogród i wizualnie oddzielająca go od sąsiednich lokacji. Na dalszych planach widoczne pozostają jedynie wysokie, drewniane słupy, które sprawiają wrażenie swobodnie rozmieszczonych w powietrzu ponad gruntem. Wygląd Snu Tropiciela jest zgodny z estetyką pejzaży symbolicznych tworzonych przez XIX-wiecznych malarzy epoki romantyzmu, którą reprezentowali Caspar David Fredrich, Carl Gustav Carus ${ }^{30}$

${ }^{29}$ Najbardziej spopularyzowane wyobrażenie kodoma jest znane szerzej za sprawą pełnometrażowej animacji o tytule Księżniczka Mononoke w reżyserii Hayao Miyazakiego ze studia Ghibli. Warto jednocześnie podkreślić, że ukształtowanie twarzy wskazanych postaci znacząco przypomina rysy jednego ze stworzeń z gry Resident Evil 3 (Capcom, 1999), które zresztą widnieje na okładce gry. Ponownie sytuuje to atmosferę Bloodborne w konwencji horroru, w każdym detalu budując poczucie niepokoju, choć bardziej na poziomie metaforycznym za pomocą rozwiązań stylistycznych.

${ }^{30}$ Artysta był także teoretykiem sztuki, który starał się przekonać odbiorców do szczególnej roli pejzażu w ówczesnym malarstwie, z uwagi na jego silny symboliczny potencjał (Carus, 1989, s. 310-322). 
czy Ernst Ferdinand Oehme. Ten rodzaj malarstwa ustanowił szereg charakterystycznych motywów, m.in. ruiny gotyckich kościołów i zamków, zamglony krajobraz w ciągu dnia lub nocny pejzaż oświetlony jedynie światłem księżyca. Koncept pejzażu romantycznego tworzą także pozbawione liści drzewa, proste, pionowo ustawione kamienne płyty nagrobne lub pojedyncze krzyże wbite w ziemię. Rezerwuar motywów stosowanych w tym typie malarstwa należy do toposów, które ogólnie podzielić można na te, w które wpisana jest natura, oraz na związane z symboliką zachodniej kultury chrześcijańskiej (Komięga, 2016, s. 35). Przy tym symbolika religijna nabiera $\mathrm{w}$ tych dziełach bardziej uniwersalnego wymiaru, odnosząc odbiorcę do kategorii takich jak wzniosłość i nieskończoność (Demokiewicz-Dobrzańska, 2013, s.100-101).

Świat Bloodborne w pełni wykorzystuje wskazane motywy i uwidacznia koncept przenikania się świata materialnego i duchowego (Copelston, 1942, s. 42). Twórcy gry, podobnie jak artyści romantyzmu, posługują się elementami świata naturalnego jako elementami symbolicznymi (Komięga, 2016, s. 38). Świat stworzony na potrzeby gry stanowi syntezę wybranych typów architektury XIX w. oraz motywów artystycznych tej epoki $^{31}$. Łączenie stylistyki neogotyku z wpisanymi w sztukę romantyzmu motywami symbolicznymi objawia się w końcowym etapie rozgrywki poprzez element fabularny, jakim jest pożar opisywanego wcześniej gotyckiego domku. To wydarzenie następuje wraz z końcem nocy łowów we Śnie Tropiciela. Na podstawie wypowiedzi bohaterów i przebiegu fabuły można wywnioskować, że owa lokacja jest dostępna dla łowców wyłącznie w czasie jednej nocy w roku, podczas polowania na potwory ${ }^{32}$. Biorąc to pod uwagę, pożar budynku widoczny zaraz po przeniesieniu się do lokacji w finalnym etapie gry symbolizuje zakończenie zarazy trawiącej miasto i tym samym snu-koszmaru, jaki stał się udziałem protagonisty. Oznaczałoby to, że istnienie tego miejsca podtrzymywała wyłącznie

${ }^{31}$ Spośród pobocznych inspiracji wskazać można na analogię między podstawowym strojem łowców i kostiumami z filmu Braterstwo wilków, a to ze względu na podobieństwo nakryć głowy i peleryn, których wysokie, zapinane na guziki kołnierze zakrywają część twarzy.

32 Wyjątkiem jest wspomniany wcześniej Gherman, którego należy uznać za opiekuna tego miejsca, na stałe z nim związanego. Jest on przewodnikiem dla nowych łowców przywołanych tam w niewyjaśnionych okolicznościach. 
obecność potężnych bestii rozproszonych po Yharnam. Niemniej żadne $\mathrm{z}$ trzech dostępnych zakończeń nie pozostawia gracza z jednoznaczną odpowiedzią w kwestii faktycznego statusu domu. Tym samym wzbudzone zostają wątpliwości co do prawdziwości wszystkich wcześniejszych wydarzeń, co osadza świat Bloodborne między tym co realne, a tym, co wyobrażone.

\section{Wnioski końcowe}

Omówione w artykule przykłady pokazują włączenie inspiracji historycznym dziedzictwem do struktury fikcyjnej świata prezentowanego w grach fantasy. Produkcje, które nie są ograniczone koniecznością wpisania się w realia danej epoki w każdym aspekcie fabuły i rozgrywki, mają większy potencjał twórczego wykorzystywania kontekstu historycznego. Paradoksalnie, fikcyjne światy są w stanie zainteresować historią większą grupę graczy poprzez subtelne implementowanie wybranych elementów znanych z rzeczywistości. W tym zakresie wskazana grupa gier nie jest uzależniona od względów marketingowych, które wynikają z chęci przystosowania treści do większej grupy nabywców. Odczytanie obecnych w grach fantasy nawiązań stanowi pewne wyzwanie i wymaga od odbiorcy podstawowej znajomości wielu tekstów kultury.

Wskazane powyżej przykłady pokazują, że choć identyfikacja poszczególnych elementów wymaga pewnych podstawowych kompetencji, wciąż działają one na gruncie stereotypów obrazowych. Dla podniesienia jakości gry wystarczy pobudzenie ogólnych obrazowych skojarzeń, które wzmacniają w graczu poczucie spójności świata przedstawionego. Natomiast atrakcyjność oferowanych graczowi światów może motywować do pogłębiania wiedzy przez poszukiwanie informacji w innych mediach. Z kolei dokładniejsze rozpoznanie może zaowocować pogłębieniem interpretacji. Przede wszystkim jednak twórcza recepcja przeszłości w grach komputerowych przynosi pozytywne rezultaty w zakresie rozwoju warstwy wizualnej i fabularnej oraz ich powiązania z mechaniką rozgrywki. Włączanie do świata gry obiektów o wybranym stylu zakłada bowiem konieczność zmian w obrębie całej struktury. Należy również uznać, iż zestaw aluzji o jednorodnym charakterze składa się na określony styl 
reinterpretowany w ramach danej gry. Łączenie realiów historycznych z elementami czysto fikcyjnymi pozwala twórcom na stosunkowo dużą swobodę kreacyjną, ułatwiając tworzenie nowej, oryginalnej formy $\mathrm{w}$ oparciu o wzorce ukonstytuowane w tradycji.

\section{Literatura}

Abt, C. C. (1987). Serious games. Lanham - New York - London: University Press of America.

Aeserth, E. (1997). Cybertext: Perspectives on ergodic literature. Baltimore: Johns Hopkins University Press.

Anderson, E., McLoughin, L., Liarokapis, F. (2010). Developing serious games for cultural heritage: A-state-of-the-art-review. Virtual Reality, 14(4), 255-275.

Balk, D. (2011). The immortality of Gothic literature: The many ways in which the contemporary Gothic work changes. Utrecht: Ultrecht University.

Bałus, W. (2011). Gotyk bez Boga? W kręgu znaczeń symbolicznych architektury sakralnej XIX wieku. Toruń: Wydawnictwo Naukowe Uniwersytetu Mikołaja Kopernika.

Beiser, F. (2011). The German historicist tradition. Oxford: Oxford University Press.

Belting, H. (2009). Miejsce obrazów (tłum. Bryl, M.). W: M. Bryl, P. Juszkiewicz, P. Piotrowski (red.), Perspektywy współczesnej historii sztuki. Antologia przekładów „Artium Quaestiones” (s. 323-338). Poznań: Wydawnictwo Naukowe Uniwersytetu im. Adama Mickiewicza.

Bissell, T. (2010). Extra lives: Why video games matter. New York: Pantheon Books.

Bogdanowska, M. (2008). Topika W: P. Wilczek (red.), Retoryka (s.35-56). Warszawa: Wydawnictwo Naukowe PWN.

Cameron, A. (2016). Pontifex Maximus: From Augustus to Gratian - and beyond. Collegium: Studies Across Disciplines in the Humanities and Social Sciences, $\mathrm{nr}$ 20, 139-157.

Carus, G. (1989). Dziewięć listów o malarstwie pejzażowym (tłum. A. Palińska). W: J. Białostocki (red.), Teoretycy, artyści i krytycy o sztuce 1700-1870, s. 470-489. Warszawa: PWN. 
Chmielewska, S. (2016). C://Hercules in Computer Games/A Heroic Evolution. W: K. Dominas, E. Wesołowska, B. Trocha (red.), Antiquity in popular culture (s. 177-187). Cambridge: Cambridge Scholars Publishing.

Copleston, F. C. (2013). Pantheism in Spinoza and the German idealists. Philosophy, 21(78), 42-56.

Czeremski, M. (2015). Problemy z „mitologizacją kultury”. W: W. Charchalis, B. Trocha (red.), Mitologizacja kultury w polskej i iberyjskiej twórczości artystycznej (s. 21-31). Zielona Góra: Pracownia Mitopoetyki i Filozofii Literatury, Uniwersytet Zielonogórski.

Curtius, E. (1997). Literatura europejska i łacińskie średniowiecze (tłum. A. Borowski). Kraków: Universitas.

Czekalski, S. (2009). Intertekstualność i malarstwo. Problem badań nad związkami międzybazowymi. Poznań: Wydawnictwo Naukowe Uniwersytetu im. Adama Mickiewicza.

Demokiewicz-Dobrzańska, K. (2013). Kategoria wzniosłości w malarstwie Caspara Davida Friedricha. Colloquium Wydziału Nauk Humanistycznych i Społecznych. Kwartalnik, 11(3), 99-117.

Fordham, J. (2012). Leaving in the past. The role history plays in video games. Statesboro: Georgia Southern University, niepublikowana praca dyplomowa.

Frank R. (2000). The invention of the Viking horned helmet. W: M. Dallapiazza, O. Hansen, P. Meulengracht Sorensen, Y. Bonnetain (red.), International Scandinavian and Medieval Studies in Memory of Gerd Wolfgang Weber (s. 199-208). Trieste: Parnaso.

Futflänger, F. (2012). God of war and mythology of games. W: T. Thorsen (ed.), Greek and Roman games in the computer age. Trondheim: Akademika Publications.

Galera, H. (2007). Morfologia a symbolika drzew. Pokrój ogólny. Nauka, nr 2, 117-129.

Gombrich, E. (1981). Sztuka i złudzenie. O psychologii przedstawienia obrazowego (tłum. J. Zarański). Warszawa: PIW.

Graham-Campbell, J. (2013). Viking art. London: Thames \& Hudson.

Górzyński, M., Ze studiów nad problemem historyzmu w polskiej historii architektury ostatniego półwiecza. Online: <http://mgarchitecturehistorian.eu/MG_Ze\%2ostudiow\%2onad\%2oproblemem\%2ohistoryzmu. pdf>. Data dostępu: 22 kwietnia 2019. 
Harris, J. (2003). Introduction. W: A. Hauser, Social history of art. Volume 1: From prehistoric times to middle ages. London - New York: Routledge. Hemeren, G. (2016). Influence in art and literature. Princteon: Princeton University Press.

Jakobsson, Á. (2011). Vampires and watchmen: Categorizing the mediaeval Icelandic undead. Journal of English and Germanic Philology, 110(3), 281-300.

Keller, J. (2008). Mr. Gatling's terrible marvel: The gun that changed everything and the misunderstood genius who invented it. New York: Viking Adult.

Komięga, P. (2016). Koncepcja pejzażu romantycznego na przykładzie twórczości Caspara Davida Friedricha na tle refleksji filozoficznych końca XVIII i początku XIX wieku. Zeszyty Naukowe Towarzystwa Doktorantów UJ. Nauki Humanistyczne, 2(13), 33-38.

Kurek, J. (2017). Norwegian stave churches - in Dietrichson and Håkon Christie research. Przestrzeń i Forma, nr 32, 64-69.

Lidow, J. (2001). Norse mythology: A guide to the gods, heroes, rituals, and beliefs, Oxford: Oxford University Press.

Lippmann, W. (1997). Public opinion. Red. R. Steel. New York: Routledge. MacLeod, M., Mees, B. (2008). Runic amulets and magic objects. Cambridge: Boydell Press.

Mazza, D. (2015). Zoomorphism in Viking Art. Journal of Ethnology and Folclorits, 9(2).

Meinecke, F. (2003). Historia i teraźniejszość (tłum. J. Kałążny). W: Opowiadanie historii w niemieckiej refleksji teoretyczno-historycznej i literaturoznawczej od oświecenia do współczesności (tłum. J. Kałążny). Poznań: Wydawnictwo Poznańskie.

O'Donoghue, H. (2007). From Asgard to Valhalla. The remarkable history of the Norse myth. New York: I. B. Tauris \& Company.

Pevsner, N. (1978). Pionierzy współczesności. Od Williama Morrisa do Waltera Gropiusa (tłum. J. Wiercińska). Warszawa: Wydawnictwa Artystyczne i Filmowe.

Ryan, M.-L. (2014). Storyworlds across media: Toward a media-conscious narratology. London - Lincoln: University of Nebraska Press.

Rodriguez, R. (2011). The Conversion of Constantine. Toronto: Lulu Press.

Roberston, D. (1976). Magical medicine in Viking Scandinavia. Cambridge Journal Medical History, 20(3), 317-322. 
Rollings, A., Adams, E. (2003). Andrew Rollings and Ernest Adams on Game Design. Boston: New Riders Publishing.

Schell, J. (2008). The art of game design: A book of lenses. London: CRC Press. Shaw, D.W. (2016). Secrets of the Viking Ships. Scandinavian Review, $\mathrm{nr} 3$, 8-21.

Schweinitz, J. (2011). Film and stereotype: A challenge for cinema and theory. New York: Columbia University Press.

Sedlmayr, H. (2007). Art in crisis: The lost center. New York: Routledge.

Tolkien J.R.R. (2001). Władca Pierścieni. Drużyna Pierścienia (tłum. M. Skibniewska). Warszawa: Warszawskie Wydawnictwo Literackie Muza SA.

Sołtysiak, M. (2015). Rogate hełmy sprzedają się lepiej? O nieprzystawalności współczesnego stanu wiedzy historycznej do potrzeb projektantów gier. Homo Ludens, 1(7), 193-208.

Szymański, M. (2017). Ożywiając antyczne wazy. Recepcja czarnofigurowego malarstwa greckiego w grze Apotheon. Kultura i Historia, 17(1). Online: <http://www.kulturaihistoria.umcs.lublin.pl/archives/6101>. Data dostępu: 13 września 2017.

Tavinor, G. (2009). The art of videogames. London: Willey-Blackwell.

Teva, V. (2013). Houses and domestic life in the Viking Age and medieval period: Material perspectives from sagas and archaeology. Nottingham: University of Nottingham.

Troeltsch, E. (2006). Religia, kultura, filozofia: wybór pism (tłum. A. Przyłębski). Poznań: Wydawnictwo Poznańskie.

Walker, M. (2003). Games that sell. Plano: Wordware Publishing, Inc.

Walton, K. (1990). Mimesis as make-believe: On the foundations of the representational arts. Cambridge, London: Harvard University Press.

\section{Ludografia}

Bethesda Game Studios (2011). The Elder Scrolls V: Skyrim [gra wieloplatformowa]. Bethesda Game Studios, USA.

SIE Santa Monica Studio (2018). God of War [Playstation 4]. Sony Interactive Entertainment, USA.

From Software (2016). Dark Souls III [gra wieloplatformowa]. Bandai Namco, Japonia.

From Software (2015). Bloodborne [Playstation 4]. Bandai Manco, Japonia. 
mgr Michał Szymański - historyk sztuki, doktorant w Instytucie Historii Sztuki UAM w Poznaniu. Przygotowuje rozprawę poświęconą estetyce gier komputerowych, ich związkom z tradycyjnymi mediami artystycznymi, takimi jak architektura i malarstwo, oraz próbie opracowania nowego, zintegrowanego modelu analizy gry jako całościowego dzieła. Autor artykułów dotyczących relacji międzyobrazowych oraz wizualności gier cyfrowych.

\title{
Kultura nordycka i gotyk jako miejsca wspólne w wirtual- nej rzeczywistości. Reprezentacja historycznych stylów na wybranych przykładach komputerowych gier fantasy.
}

\begin{abstract}
Abstrakt: Celem artykułu jest rozważenie związku gier komputerowych z dziedzictwem kulturowym, które jest świadectwem określonych epok historycznych. Inspiracja dawną architekturą, rzeźbą i malarstwem, o charakterze cytatów czy aluzji, pojawia się w wielu realizacjach, co pozwala mówić o odrębnym zjawisku, które wymaga badań. Spojrzenie na gry z perspektywy historyka sztuki pozwala dostrzec wiele nowych aspektów tworzenia wirtualnych światów przez deweloperów gier. Przykładami są gry fantasy, które szeroko odwołują się do dziedzictwa kulturowego. Tekst przedstawia przykłady kilku produkcji odtwarzających sztukę z danego okresu, skupiając się na repertuarze wybranych tematów. Analizy poprzedza przegląd stanu badań nad zagadnieniem interpretacji historii w grach komputerowych. Natomiast krytyka uproszczeń historycznych w grach sformułowana przezjednego z badaczy stanowi podstawę do dalszej refleksji nad pozytywnymi aspektami interpretacji przeszłości w grach fantasy.
\end{abstract}

Stowa kluczowe: gry komputerowe, dziedzictwo historyczne, styl gotycki, sztuka nordycka 
